\title{
Bioconversion of Single Cell Protein from Underutilised Seaweed Turbinaria sp. using Natural Palmyrah Toddy Yeast
}

\author{
S. Shayanthavi* and R. Kapilan \\ Department of Botany, University of Jaffna, Sri Lanka
}

Date Received: 10-05-2021

Date Accepted: 30-05-2021

\begin{abstract}
This study was aimed to produce Single Cell Protein (SCP) from underutilied, abundantly found marine seaweed Turbinaria sp. using natural yeast from palmyrah (Borassus flabellifer) toddy. Turbinaria sp. were collected, sun-dried, ground to powder form and Turbinaria solution was made by mixing distilled water and this was used as a growth medium throughout the experiment without adding any supplements. The experiments were performed in a shaking incubator with the fermentation medium of Turbinaria sp. $100 \mathrm{~g} / \mathrm{L}(10 \%)$ inoculated with $10 \mathrm{~mL}$ natural palmyrah toddy. Fermentation was carried out at $29^{\circ} \mathrm{C}$ for $72 \mathrm{~h}$ and the crude protein content was determined using Kjeldahl apparatus $(38.46 \%)$. When the growth temperature was optimised at $35^{\circ} \mathrm{C}$, crude protein yield obtained was significantly increased by 1.36 times than the initial non-optimised condition with temperature $27^{\circ}$ C. When fermentation time was optimised as $48 \mathrm{~h}(44.33 \%)$, crude protein yield was significantly increased by 1.14 times than the initial fermentation time ( $24 \mathrm{~h}-38.55 \%)$. When different combinations of Turbinaria sp. media and inoculum ratio (55:05, 50:10, 40:20, 30:30 and 20:40) were used as medium, crude protein yield was significantly increased by 1.44 times $(50: 10-43.72 \%)$ than the initial media inoculum ratio (55:05-30.21\%). When initial $\mathrm{pH}$ of the media was changed (5.0, 6.0, 7.0, 8.0 and 9.0), significantly higher relative crude protein yield was obtained with the initial $\mathrm{pH}$ value 6.0 (Turbinaria medium-90.97\%). Amino acid analysis revealed that the SCP produced from the Turbinaria medium had all the essential amino acids with comparatively higher amount of methionine $(3.9 \%)$ and lower amount of threonine $(0.2 \%)$. Vitamin B analysis revealed that SCP yield from Turbinaria medium contained thiamin $(0.85 \mathrm{mg} / 100 \mathrm{~g})$ and riboflavin $(3.2 \mathrm{mg} / 100 \mathrm{~g})$. After the optimisation of culture growing conditions and media composition, SCP production from the excessively grown, underutilised seaweed Turbinaria, was significantly increased by 1.13 times (from 38.46 to $43.72 \%$ ) with palmyrah toddy mix.
\end{abstract}

Key words: crude protein, palmyrah toddy mix, single cell protein (SCP), Turbinaria sp.

\section{Introduction}

Due to the steep increasing global population, the need for food supply increases day by day for human and animals. Therefore, shortage of protein is becoming a serious challenge for both human and animals. To overcome this protein shortage, Single Cell Protein (SCP) is used as a protein supplement for both human and animals. The SCP is an edible protein which is extracted from dried cell biomass from various microorganisms. These dried biomass contain proteins, lipids, carbohydrates, nucleic acids, vitamins and minerals (Ware, 1997). The concept of using microorganism is an innovative way to solve the global food issue (Nasseri et al., 2011). Microorganisms like bacteria, yeast, marine microalgae and molds are used in SCP productions by utilising cheap materials as substrate (Srividya et al., 2013). The natural toddy can be used as a mixed culture of bacteria, yeast and fungus in the SCP production (Rajendran et al., 2018).

*Correspondence: shayanth1995@gmail.com

Tel: +94773377363

(C) University of Sri Jayewardenepura

38 
Tappers climb on the palmyrah palm and sweet sap is obtained by tapping the inflorescence of palmyrah palm. Tappers store the sweet sap in the pot that hangs on the top of the palm. Unfermented sap is converted into alcoholic toddy by the wild yeast and bacteria that present in the toddy collecting pot (Theivendirarajah, 1978). The northern region of Sri Lanka has various seaweeds abundantly along the coast (Coppejans et al., 2009). In this study, seaweed Turbinaria sp. was selected as source of SCP because of its high nutritional value and abundantly found around Jaffna peninsula (Jeyaseelan et al., 2012). Therefore it was decided to explore the possibility of producing single cell protein from one of the abundantly found under-utilised marine plant species Turbinaria sp. as substrate with the aid of natural palmyrah toddy yeast. The study was aimed to optimise the culture conditions to increase the SCP yield from Turbinaria sp. and to determine the compositions of vitamin B and amino acids in the SCP.

\section{Materials and Methods}

\subsection{Collection of substrates}

Seaweed Turbinaria sp. was collected and ground into fine powder. Fresh palmyrah toddy was obtained during October to February in the year 2019-2020.

\subsection{Preparation of substrates}

Ten grams of Turbinaria sp. powder digested in $100 \mathrm{~mL}$ of distilled water and extracted using muslin cloth. Filtered liquid of Turbinaria was used as growth medium.

\subsection{Preliminary study}

Filtered liquid of Turbinaria was used as growth medium. Fifty milliliters of Turbinaria medium was added to $250 \mathrm{~mL}$ conical flasks separately. Then $10 \mathrm{~mL}$ of natural palmyrah toddy was added to the medium. Erlenmeyer flasks of $250 \mathrm{~mL}$ were kept for liquid state fermentation in an orbital shaker at $100 \mathrm{rpm}$ for $72 \mathrm{~h}$ at $29^{\circ} \mathrm{C}$. After fermentation, the pellets were obtained by centrifugation at $4,000 \mathrm{rpm}$ for 15 minutes and pellets were dried in the oven at $45^{\circ} \mathrm{C}$ for $24 \mathrm{~h}$. Then the Kjeldahl method was used to determine the crude protein content (Plaza et al., 2013).

\subsection{Optimisation of SCP production}

(a) Effect of temperature

Optimisation of temperature was carried out at various temperatures such as $27^{\circ} \mathrm{C}, 30^{\circ} \mathrm{C}, 32^{\circ}$ $\mathrm{C}, 35^{\circ} \mathrm{C}$ and $40^{\circ} \mathrm{C}$.

\section{(b) Effect of fermentation time}

Fermentation was carried out for different days of 1 to 5 days at $35^{\circ} \mathrm{C}$ in $100 \mathrm{rpm}$ shaking incubator.

\section{(c) Effect of media inoculum ratio}

Fermentation was carried out in different media inoculum ratio such as 55:05, 50:10, 40:20, $30: 30$ and $20: 40$ at $35^{\circ} \mathrm{C}$ for $48 \mathrm{~h}$ in $100 \mathrm{rpm}$ shaking incubator.

\section{(d) Effect of $p H$}

Relative crude protein yield was compared in different $\mathrm{pH}(5,6,7,8$ and 9). Fermentation was carried out at $35^{\circ} \mathrm{C}$ for $48 \mathrm{~h}$ in $100 \mathrm{rpm}$ shaking incubator. After each experiment, crude protein content was determined using Kjeldahl apparatus.

(e) Determination of amino acids composition of SCP

Amino acid composition was determined before and after fermentation process using amino acid analyser (Erdman et al., 1977). 
(f) Determination of vitamin B composition of SCP

Vitamin B content was determined before and after fermentation using High Performance Liquid Chromatography (Giorgi et al., 2012)

\subsection{Statistical analysis}

All the experiments were done in triplicates and the mean values were used to plot the graphical representation. Statistical analyses were performed using Minitab 17.0 version. The data were analysed by one way ANOVA and paired T-test was used to determine significant differences at $\mathrm{p}<0.05$.

\section{Results and Discussion}

\subsection{Effect of temperature}

Incubation temperature is one of the main factors that have an effect on SCP production (Fatmeh et al., 2019). In this study, significantly higher SCP yield was obtained at $35^{\circ} \mathrm{C}$ at $100 \mathrm{rpm}$ for 3 days of fermentation (41.41\%-Figure 1) than the other temperatures used. Effect of temperature on SCP yield reveals the protein content nearly $47.78 \%$ at $30^{\circ} \mathrm{C}$ by using sugar bagasse as the substrate (Razzaq et al., 2020). In another study, higher SCP yield was obtained at $35^{\circ} \mathrm{C}$ with Aspergillus fumigatus (Hezarjaribi et al., 2015). Even though SCP production at temperatures between $30-50^{\circ} \mathrm{C}$ under liquid state fermentation system is satisfactory, the SCP yield was significantly higher at $35^{\circ} \mathrm{C}$ after 3 days of fermentation. Since the crude protein yield was significantly higher in $35^{\circ} \mathrm{C}$, this temperature was chosen for further studies.

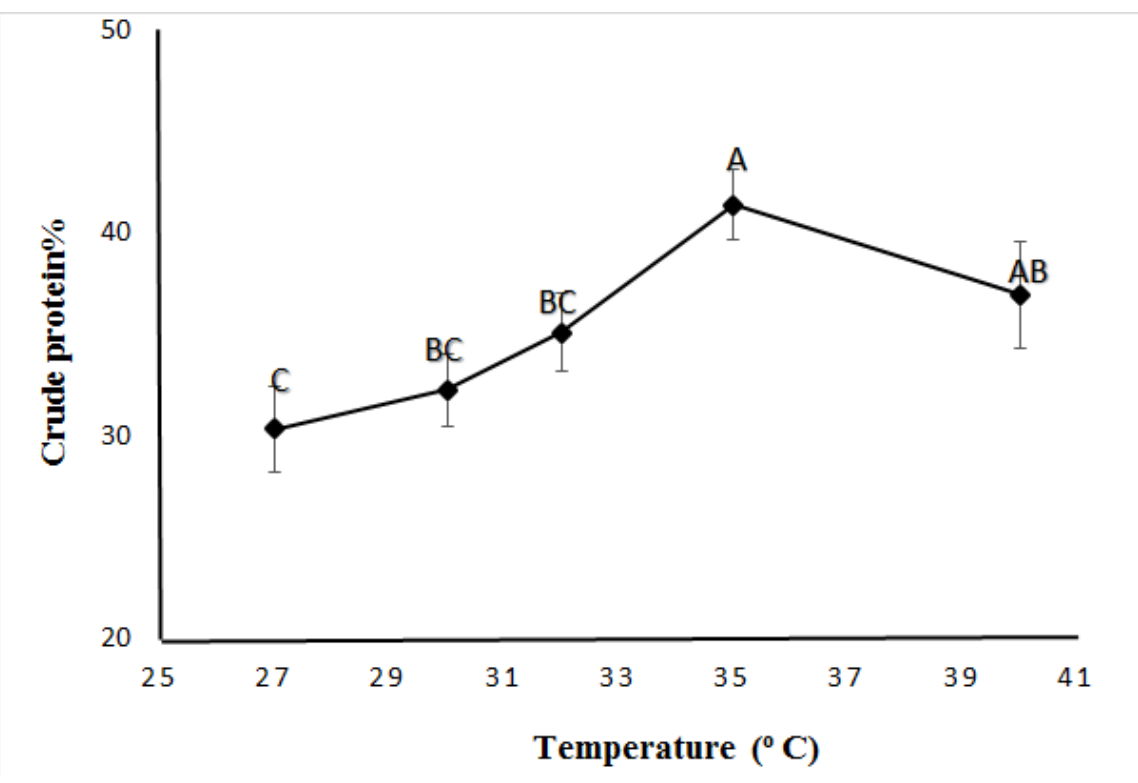

Figure 1. Effect of incubation temperature on SCP production from Turbinaria sp. substrate using natural palmyrah toddy yeast under liquid fermentation system.

\subsection{Effect of fermentation time}

Quantity of SCP increased with increasing fermentation time from the $1^{\text {st }}$ day till the end of $2^{\text {nd }}$ day (Figure 2). After 2 days of fermentation, crude protein of SCP production started to decline. Significantly higher SCP yield was obtained on the $2^{\text {nd }}$ day of fermentation (44.33\%-Figure 2), thus 2 days of fermentation time was chosen for further studies. Similar observations were made in an experiment carried out with papaya juice (Rajendran et al., 2018), sugarcane bagasse using yeast (Samadi et al., 2016) and with pineapple waste using yeast (Dhanasekaran et al., 2011). 


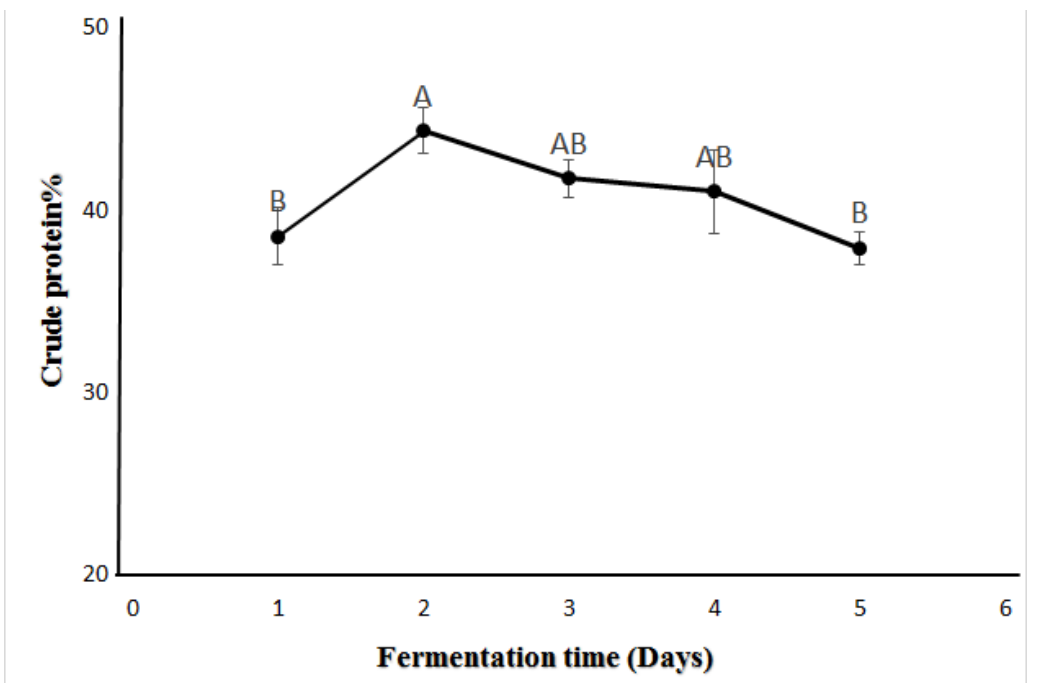

Figure 2. Effect of fermentation time on SCP production from Turbinaria sp. substrate using natural palmyrah toddy yeast under liquid fermentation system.

\subsection{Effect of media inoculum ratio}

SCP yield from the container that had inoculum ratio of 55:05 was significantly lower $(30.20 \%)$ than the others. There were no significant differences in the SCP yield when media inoculum ratios were maintained as 50:10, 40:20 and 30:30 (Figure 3). The amount of crude protein quite higher in the ratio of 50:10. Therefore 50:10 ratio was selected for further optimisation. In another study, maximum yield obtained at an inoculum size of $10 \%(\mathrm{~V} / \mathrm{M})$ in the SCP production through microbial conversion of wheat bran for animal feed (Yunus et al., 2015).

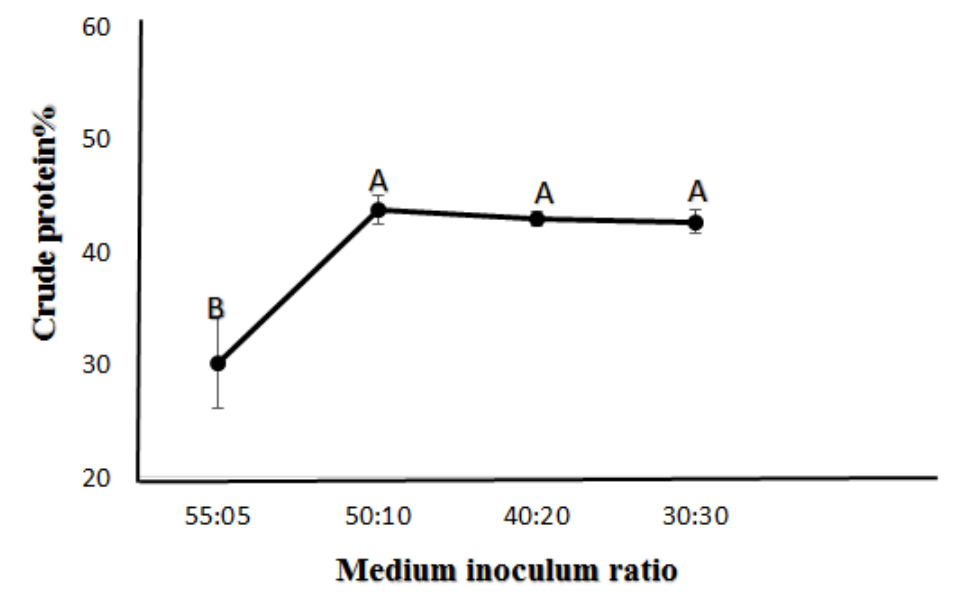

Figure 3. Effect of medium inoculum ratio on SCP production from Turbinaria sp. substrateusing natural palmyrah toddy yeast under liquid fermentation system.

\subsection{Effect of $p H$}

Since $\mathrm{pH}$ of the media will affect the growth and metabolic activities of the fermenting microorganisms, it was decided to perform an SCP production experiment with media of different $\mathrm{pH}$ values. There were no significant differences in the SCP yield produced when the $\mathrm{pH}$ of the media was 5.0, 6.0 and 7.0 (Figure 4). Similarly, there were no significant differences in the SCP yield, when the 
pH of the media was set at 8.0 and 9.0 (Figure 4). In another study, SCP production was significantly higher at pH 6.0 when rice was used as substrate in the presence of Candida utilis (Rajoka et al., 2003).

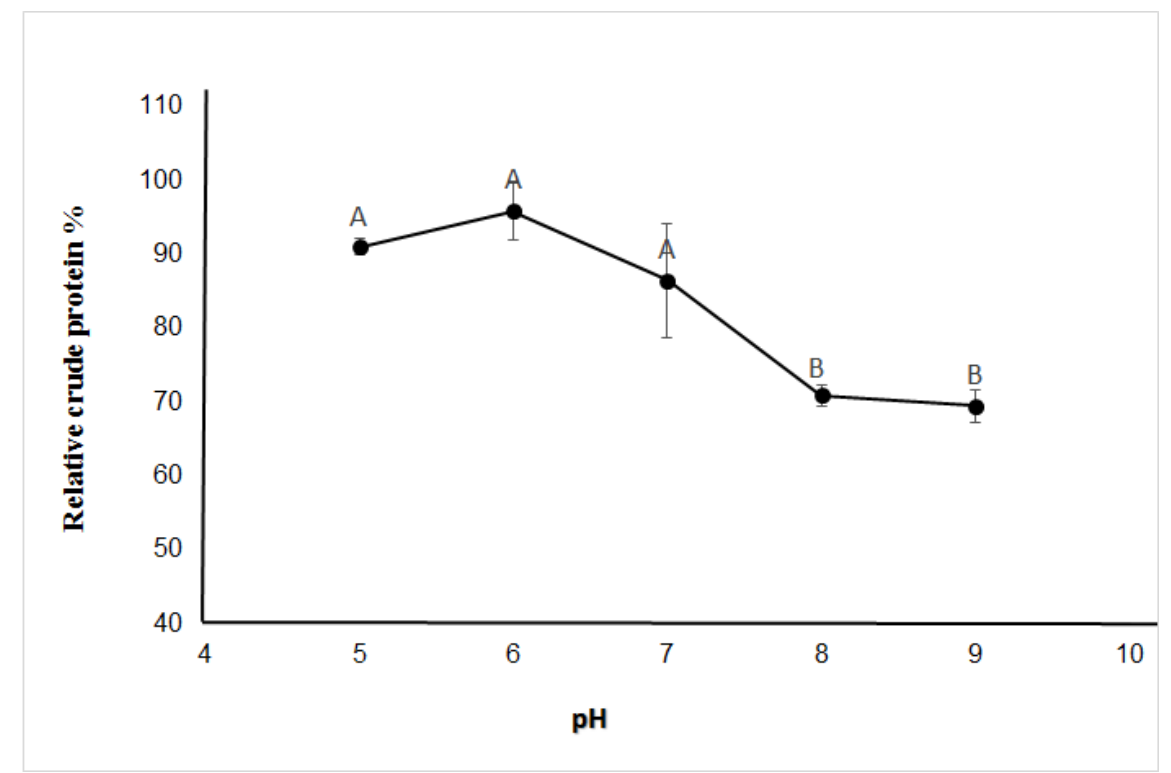

Figure 4. Effect of $\mathrm{pH}$ on SCP production from sea weed Turbinaria sp. as substrate using natural palmyrah toddy yeast under liquid fermentation system.

\subsection{Determination of amino acid composition}

Amino acid analysis after fermentation revealed that amino acids methionine and leucine were found to be in significantly higher quantities in Turbinaria, whereas threonine and lysine were found to be in significantly lower quantities than other amino acids. Similar observations were obtained in the study of SCP production from banana juice (Rajendran et al 2018). Amount of all the essential amino acids have been increased after fermentation compared to the amount before fermentation. Quantities of amino acids such as tryptophan, methionine, leucine and arginine were significantly increased after fermentation. Bioconversion of substrates into microbial enzymes may lead to the increase of some amino acids during fermentation (Oseni and Akindahunsi, 2011). There were no significant difference in the amount of lysine, threonine, valine, isoleusine, glutamate, phenylalanine and histidine before and after fermentation (Table 1).

Table 1: Amino acid composition (\% dry matter) obtained from SCP produced from the seaweed Turbinaria sp. as medium.

\begin{tabular}{|c|c|c|}
\hline \multirow{2}{*}{ Amino acids } & \multicolumn{2}{|c|}{ Amount (\% dry matter) } \\
\hline & (Before fermentation) & (After fermentation) \\
\hline Lysine * & 0.2 & 0.4 \\
\hline Tryptophan * & 1.2 & $2.5 \#$ \\
\hline Threonine* & 0.2 & 0.2 \\
\hline Methionine * & 1.9 & 3.9\# \\
\hline Valine $*$ & 1.8 & 2.4 \\
\hline Isoleucine $*$ & 0.7 & 1.0 \\
\hline Leucine * & 2.2 & $2.8 \#$ \\
\hline Glutamate & 0.9 & 1.1 \\
\hline Phenylalanine* & 0.2 & 0.6 \\
\hline Histidine* & 0.3 & 0.5 \\
\hline Arginine & 1.6 & 2.1\# \\
\hline
\end{tabular}

Essential amino acids are denoted using*

Significant increase is denoted using\# 


\subsection{Determination of vitamin B composition}

Vitamin B components such as thiamin and riboflavin were found in the SCP from Sea weed Turbinaria where as other vitamin components were absent or in trace levels that cannot be measured. Thiamin and riboflavin type vitamin B was reported in the SCP produced from dextrose medium using Candida tropicalis (Wijeyeratne and jayathilaka, 2000). There were no significant difference in the level of thiamin and riboflavin before and after fermentation (Table 2).

Table 2: Thiamin and Riboflavin content (mg/100 g) of SCP produced from seaweed Turbinaria sp. as medium.

\begin{tabular}{lcc}
\hline \multirow{2}{*}{ Vitamin B } & \multicolumn{2}{c}{ Weight } \\
\cline { 2 - 3 } & (Before fermentation) & (After fermentation) \\
\hline Thiamin & 0.75 & 0.85 \\
Riboflavin & 2.25 & 3.20 \\
\hline
\end{tabular}

\section{Conclusion}

Single cell protein was produced from abundantly available marine weed Turbinaria sp. using natural yeast found in palmyrah toddy mixed culture under optimised conditions. Optimisation of condition such as fermentation time $(72 \mathrm{~h})$, temperature $\left(35^{\circ} \mathrm{C}\right)$, source of inoculum $(50: 10), \mathrm{pH}$ of the media (6) increased the yield by 1.136 times. After the optimisation of the culture growing conditions and media composition, SCP production was significantly increased from 38.46 to $43.72 \%$ (1.13 times). SCP produced from marine weed Turbinaria contained all the essential amino acids to human as well as vitamin B components thiamin and riboflavin. In that, amount of amino acids such as tryptophan, methionine, leucine and arginine show significant increase after fermentation.

\section{Acknowledgement}

Authors wish to express their sincere gratitude to the University of Jaffna for providing the financial support to undertake this project.

\section{References}

Coppejans, E., Leliaert, F., Dargent, O., Gunasekara, R. and Clerck, O., 2009. Methodologies and field guide to the dominant species. Sri Lankan seaweeds, 6:5-15.

Dhanasekaran, D., Lawanya, S., Saha, S., Thajuddin, N. and Panneerselvam, A., 2011. Production of single cell protein from pineapple waste using yeast. Innovative Romanian food biotechnology, 8:26-32.

Erdman, M.D., Bergen, V.G. and Reddy, A., 1977. Amino acid profiles and presumptive nutritional assessment of SCP from certain Lactobacilli. Applied and environmental microbiology, 33:901905.

Fatmeh, S., Reihani, S. and Dharani, K.K., 2019. Influencing factors on single-cell protein production by submerged fermentation: A review. Electronic journal of biotechnology, 37:34-40.

Giorgi, M.G., Howland, K., Martin, C. and Bonner, A.B., 2012. A Novel HPLC Method for the Concurrent Analysis and Quantitation of Seven Water-Soluble Vitamins in Biological Fluids. Scientific world journal, 6.

Hezarjaribi, M., Ardestani, F. and Ghorbani, H.R., 2015. Optimization of Single Cell Protein Production by Aspergillus fumigatus using a Fraction of the Full Factorial Method. International Journal of darshan institute on engineering research and emerging technologies, 4. 
Jeyaseelan, E.C., Kothai, S., Kavitha, R., Tharmila, S. and Thavaranjit, A.C., 2012. Antibacterial activity of some selected algae present in coast line of jaffna peninsula. International Journal of Pharmaceutical \& Biological Archives, 3:352-356.

Nasseri, A.T., Morowvat, M.H., Amini, R.S. and Ghasemi, Y., 2011. Single cell protein: production and process. American journal of food technology, 6:103-116.

Oseni, O.A. and Akindahunsi, A.A., 2011. Some phytochemical properties and effect of fermentation on the seed of Jatropha curcas L. American journal of food technology, 6:158-165.

Plaza, S., Navas, M.J., Wybraniec, S., Michalowski, T. and Asuero, A.G., 2013. An overview of the Kjeldahl method of nitrogen determination, 43:224-272.

Rajendran, S., Kapilan, R. and Vasantharuba, S., 2018. Single cell protein production from papaya and banana fruit juices using baker's yeast, International Forestry and Environment symposium, 18:168-172.

Rajendran, S., Kapilan, R. and Vasantharuba, S., 2018. Papaw fruit juice as source for single cell protein production using natural palmyrah toddy yeast. Ceylon Journal of Science, 47:379-386.

Rajoka, M.I., Kiani, M.A.T., Khan, S., Awan, M.S. and Hashmi, A.S., 2003. Production of single cell protein from rice polishing using Candida utilis. World Journal of Microbiology and Biotechnology, 20:297-301.

Razzaq, Z., Khan, M. and Maan, A., 2020. Characterization of single cell protein from Saccharomyces cerevisiae for nutritional, functional and antioxidant properties. Journal of Food Measurement and Characterization, 14:2520-2528.

Samadi, S., Mohammadi, M. and Najafpour, G.D., 2016. Production of single cell protein from sugarcane Bagasse by Saccharomyces cerevisiae in tray bioreactor. International Journal of Engineering, 29:1029-1036.

Srividya, A.T., Vishnuvarthan, V.J., Murugappan, M. and Dahake, P.G., 2013. Single cell protein, International Journal for Pharmaceutical Research Scholars, 2:472-485.

Theivendirarajah, K. and Krystopher, K., 1986. Chemical analysis of palmyrah palm Borassus flabelliferL.wine ("Toddy").Vingnanam Journal of Science, 1:1-7.

Ware, S.A., 1997. Single cell protein and other food recovery technologies from waste, municipal environmental research laboratory, Office.

Wijeyaratne, S.C. and Jayathilake, A.N., 2000. Characteristics of two strains (Candida tropicalis) isolated from Caryota urens (kithul) toddy for single cell protein production. Journal of National Science Foundation Sri Lanka, 28:79-86.

Yunus, F.U.N., Nadeem, M. and Rashid, F., 2015. SCP production of microbial conversion of wheat bran for animal feed. Researchgate, 121. 